\title{
Hepatitis E Virus Antibody Measurement
}

National Cancer Institute

\section{Source}

National Cancer Institute. Hepatitis E Virus Antibody Measurement. NCI Thesaurus. Code C119283.

The determination of the amount of hepatitis E virus antibody in a biological specimen. 